\title{
Nordic-Baltic cooperation in the field of adult education 1991-2004
}

\author{
Larissa Jõgi ${ }^{1}$ - Margarita Teresevičiené ${ }^{2} \cdot$ Tatjana Kokge $^{3} \cdot$ Arne Carlsen $^{4}$ \\ Published online: 26 June 2018 \\ (C) Springer Nature B.V. and UNESCO Institute for Lifelong Learning 2018
}

The awakening of the three Baltic countries following the Singing Revolution ${ }^{1}$ at the very end of the 1980s led to the restoration of independence in 1991 of Estonia, Latvia and Lithuania. Being the Baltic states' closest neighbours, the Nordic countries were among the first who offered to share their ideas and expertise in adult education, but they were also keen to learn more about and from the Baltic states. This took place several years before the Baltic states joined the European Union in 2004. In analysing the educational and social changes in the Baltic states during this period (1991-2004) as an example of transformational changes in Estonia, Lithuania and Latvia, the articles in this special issue demonstrate that NordicBaltic cooperation in adult education has resulted in establishing a strong NordicBaltic adult education network and in creating a new identity for adult educators. This network continues to serve today as a base and resource for knowledge and innovation, experience, values and pedagogical practices in the field of adult education and social development at both national and regional levels.

\footnotetext{
1 The Singing Revolution (1987-1991), was a series of peaceful protests held in the three Baltic states during Soviet occupation. These protests led to the restoration of the independence of Estonia, Latvia and Lithuania.
}

Arne Carlsen

carlsenarne@gmail.com

Larissa Jõgi

larj@tlu.ee

Margarita Teresevičienè

margarita.tereseviciene@vdu.1t

Tatjana Kokse

tatjana.koke@gmail.com

1 School of Educational Sciences, Tallinn University, Tallinn, Estonia

2 Vytautas Magnus University, Kaunas, Lithuania

3 Riga Stradins University, Riga, Latvia

4 Danish School of Education, Aarhus University, Aarhus, Denmark 
Adult education is a field that builds on humanistic values, including the value of the exchange of experiences and cooperation among people. It is full of life stories from professionals, policy makers and adult educators which can help to understand trends in the past and developments in the present. Established in 1991 as part of a more general regional cooperation among five Nordic and three Baltic countries, Nordic-Baltic cooperation in adult education has been mutually enriching and has resulted in the growth of both professional and research networks. The cooperation has led the participants through a time of new values, knowledge and contacts, socialisation and transformation, inspiration and challenges, which have shaped their experiences and professional identity. It has supported them in their work to educate, to organise learning environments, and in their endeavours to lead education processes. This lifelong learning framework expanded into life-wide learning in different environments - formal, non-formal and informal -, embracing adults of different life and professional backgrounds.

These achievements would not have been possible without substantial institutional, organisational and personal input into the development of a professional identity and professionalisation of adult educators. Since the beginning of the 1990s, the role and possibilities of adult education and professional development of adult educators in the Baltic countries were growing rapidly, and this growth was largely owing to strong cooperation with the Nordic countries. The role of the Nordic Folk Academy in Gothenburg, ${ }^{2}$ the Nordic and Baltic Council of Ministers, ${ }^{3}$ ministries in all Nordic and Baltic countries, the emerging national adult education associations, universities and non-governmental organisations, cultural institutions and municipal structures, and hundreds of adult educators who invested a big part of their professional and private lives in this process, cannot be underestimated. However, to date, very little research has been done on this process. The articles in this special issue are among the first of their kind, and will hopefully open up a new research area.

The first article in this special issue is entitled "Nordic-Baltic cooperation in adult education: A collective story of Estonian adult educators". Larissa Jõgi and Katrin Karu give an analytical overview and phenomenological impression of experiences and formation of professional identities of two generations of Estonian adult educators during the period 1991-2004. The authors present results from research on "Nordic-Baltic cooperation in adult education: Experience and stories". Based on a phenomenological, interpretive paradigm (Finlay 2009, Van Manen

\footnotetext{
2 "The Nordic Folk Academy (NFA; Nordens Folkliga Akademi in Swedish), was founded in 1968 as a non-profit organisation in Kungälv near Gothenburg. [It moved to Gothenburg in 1991.] It was a meeting place (with a library, a lecture hall, several group and meeting rooms and 30 single guest rooms) aiming to foster and develop co-operation among adult educators from the Nordic and adjacent countries as well as other European countries. It closed down in 2004" (Teresevičienè et al. 2017). Teresevičiené, M., Trepule, E. \& Trečiokienè, E. (2017). The impact of Nordic adult education ideas on the development of a democratic society in Lithuania. International Review of Education (this issue). https://doi.org/10.1007/ s11159-017-9627-4.

3 The Nordic Council of Ministers (NCM) "is the official body for inter-governmental cooperation in the Nordic region. It seeks solutions with positive effects for everybody who lives in the Nordic countries" (http://www.norden.org/en/nordic-council-of-ministers/the-nordic-council-of-ministers/the-history-ofthe-nordic-council-of-ministers [accessed 14 June 2018]).
} 
2005, Patton 2002) ${ }^{4}$ this research adopted a narrative-biographical approach (Chamberlayne 2004), ${ }^{5}$ through which the professional identity of Estonian adult educators in the context of their life course was analysed. The article focuses on two aspects: (1) the perception and influence of experiences for adult educators; and (2) the influence of their experiences on the professional identity of adult educators. Estonian adult educators hold and maintain the social values of the Nordic educational paradigm. These values are: trustfulness, freedom, joint actions, equality, understanding the human being as learner, a belief that at the centre of education is the human being, and that the adult educator is the agent of culture and supporter of adult learning.

The second and third articles in this special issue focus on the influence of Nordic countries on developments in the field of adult education in Lithuania.

In their article entitled "The impact of Nordic adult education ideas on the development of a democratic society, Margarita Teresevičiené, Elena Trepule and Edita Trečiokiene analyse the role of cooperation and the impact of Nordic adult education ideas on the development of a democratic society in Lithuania. The Nordic model of adult education constitutes an example of the role of adult education in the successful development of a democratic welfare society and has influenced adult education in Lithuania since the restoration of independence in March 1990. However, the cooperation was never a question of direct transfer of a Nordic model or promoting/fostering the country to implement it as such. On the contrary, the Nordic countries inspired Lithuania to build a new educational system and a new democracy using its own potential.

The influence of the Nordic countries on the development of the democratic society in the Baltic states happened through a planned as well as informal cooperation in the field of adult education. In Lithuania the major influence may be clustered into three main areas: (1) training of Lithuanian adult educators; (2) establishment and development of NGOs; and (3) implications on the policy of adult education. However, the internalisation of new democratic values was more complicated than expected for many politicians, adult educators and NGO leaders in the way that political decisions were perceived and implemented.

The article "Development of the profession and qualifications of adult educators in Lithuania in the context of reforms of adult education", written by Genute Gedvilienè, Vidmantas Tūtlys, Vilija Lukošiūnienè and Vaiva Zuzevičiūtè, analyses the professionalisation of adult educators in Lithuania in the context of the historical-institutional and the political-economical development of adult education and lifelong learning. The authors argue that despite important achievements in the

\footnotetext{
${ }^{4}$ Finlay, L. (2009). Debating phenomenological research methods. Phenomenology \& Practice, 3(1), 6-25.

Van Manen, M. (2005). Writing in the dark. Phenomenological studies in interpretive inquiry. London, ON: The Althouse Press.

Patton, M. (2002). Qualitative research and evaluation methods. Thousand Oaks, CA: Sage Publications.

5 Chamberlayne, P. (2004). Biographical methods and social policy in European perspective. In P. Chamberlayne, J. Borna t\& U. Apitzsch (Eds), Biographical methods and professional practice: An international perspective (pp. 19-38). Bristol: Policy Press.
} 
legal regulation and recognition of their professional status and qualifications, adult educators are still encountering significant challenges in their efforts to strengthen their socio-economic status.

Latvia's reflection on the experience of a unique cooperation between Nordic and Baltic countries in adult education is revealed in the article by Antra Carlsen and Elina Maslo, entitled "Growing Together: A Latvian retrospective of learning opportunities created in the cooperation among Nordic and Baltic adult educators". The article tells the extraordinary story of how Latvian adult educators were trained, trained themselves, taught others, conducted research on adult learning and developed a system of adult education as a result of the cooperation with the Nordic partners. The authors trace the evolution of this cooperation and conclude that it started as "donorship" from the Nordic side and grew into "a partnership" between equals. Adopting an ecological sociocultural perspective on learning and learning opportunities, the authors seek to understand how learning opportunities were created and implemented in Latvia and to identify what makes international cooperation meaningful, successful and productive.

The main objective of this special issue is to reflect on and evaluate the experience of adult educators who have been involved in Nordic-Baltic cooperation projects since the early 1990s and to valorise its impact on recent developments in Baltic adult education. Up to now, very little research has been done to assess the effect of this particular example of mutual inspiration and support. Therefore, much of the research going into the articles in this special issue is based on qualitative interviews and life stories. We fervently hope that more studies will be conducted soon - while the pioneers of this cooperation are still around.

The guest editors and the authors also hope that this special issue will contribute to a continuation of the dialogue and cooperation among practitioners, researchers and policymakers inside but also outside of the Nordic-Baltic region. The potential to benefit from first-hand accounts of this cooperation, to identify new policies and actions in a field of high topicality, is considerable, given the current (and increasing) need for multicultural learning, for healthy living in aging societies, and for upskilling people of all ages. These issues are just a few of the current and future trends in adult education, related to fast-moving changes in global society. There is no doubt that they are of high importance and constitute a strong platform for further cooperation among adult educators, both within the Nordic-Baltic region and networks, and worldwide.

Larissa Jõgi $(\mathrm{PhD})$ is a professor and the head of the Lifelong and Non-Formal Education study area in the School of Educational Sciences at Tallinn University. She is a founding member of the European Society for Research on the Education of Adults (ESREA) research network on Adult Educators, Trainers and their Professional Development and a member of the International Society for Comparative Adult Education (ISCAE). In addition, Larissa Jõgi is a member of the Nordic-Baltic Network in Higher Education, a member of the Estonian Adult Education Council, a member of the editorial advisory board of the European Journal for Research on the Education and Learning of Adults (RELA) and an editor of the journal Studies for the Learning Society. Her research interests include adult learning, biographical learning, emotional learning experiences, and learning and teaching at the university. 
Margarita Teresevičiene is a professor at the Department of Educational Sciences of Vytautas Magnus University in Kaunas, Lithuania. Her research interests relate primarily to adult education and learning, recognition of prior learning as well as technology-enhanced learning. She has supervised more than ten doctoral theses on adult learning. She acts as an expert in the field of adult education for the Lithuanian Ministry of Education and Science; for the Research Council of Lithuania as well as for the European Commission. Margarita is also a member of the Lithuanian Adult Education Association. She has been involved in a number of European programmes and projects (FM6, ERASMUS+, NORDPLUS), producing documents and carrying out studies in the field of lifelong learning on national and international levels.

Tatjana Koke Dr habil. paed. is Vice Rector for Education at Riga Stradins University in Latvia, professor of adult education and lifelong learning, and a senior researcher at the University of Latvia. She ia a former Minister of Education and Science, Republic of Latvia (2007-2010), Corresponding member of the Latvian Academy of Sciences, and an expert of quality assurance at the Latvian Higher Education Quality Agency (AIKA). She has been a Board member of the European Adult Education Association (EAEA) (2006-2008) and Vice president and member of the Council of International Bureau of Education (IBE), UNESCO (2004-2008). In 2008 she joined the Editorial Board of Prospects, UNESCO's Quarterly Review of Comparative Education. Under her supervision, nineteen doctoral students have earned a $\mathrm{PhD}$ degree in Education. Since 2011 she has been participating in the AsiaEurope Meeting Education and Research Hub for Lifelong Learning (ASEM LLL Hub). She has been a guest lecturer at Vytautas Magnus Kaunas University, Lithuania; Arhus University, Denmark; Stockholm University, Sweden; Fribourg University, Switzerland (within the Swiss Baltic Net cooperation); Columbia University, NY, USA, Lehigh University, PA, USA; the University of Sussex, UK; The University of British Columbia, Canada; and the University of Iceland. She has written over 100 scholarly papers, including three monographs, 65 articles, and 37 essays. Herresearch interests are: Lifelong Learning, Adult Education, Quality Assurance in Adult education, and Internationalisation of Higher Education.

Arne Carlsen Prof (Hon), Dr h.c. mult. is a Senior Advisor at the Danish School of Education, Aarhus University. He is a former Director of the UNESCO Institute for Lifelong Learning (2011-17) and former Chair of the Editorial Board of the International Review of Education - Journal of Lifelong Learning. He is honorary Professor, Chair Professor or Honorary Doctor at 10 universities around the world, and a member of the International Adult and Continuing Education Hall of Fame. He founded the Asia-Europe Meeting Education and Research Hub for Lifelong Learning (ASEM LLL Hub), a research network for 40 universities in Asia and Europe. He is a former Lecturer and former Rector of the Nordic Folk Academy (NFA) in Gothenburg, Sweden. and he founded the Nordic-Baltic Summer Academies shortly after the Baltic countries regained their independence in 1991. He has been a Visiting Professor at Vytautas Magnus University in Kaunas, Lithuania, and has received the Letter of Honour from the Lithuanian Ministry of Education. He is a member of the Steering Committee of the Doctoral School of Lifelong Learning at the University of Latvia and Honorary Doctor from that same university. He has received the coin of the Estonian Ministry of Education. 